\title{
Is the International Role of the Dollar Changing?
}

\author{
Linda S. Goldberg
}

Recently the U.S. dollar's preeminence as an international currency has been questioned. The emergence of the euro, changes in the dollar's value, and the financial market crisis have, in the view of many commentators, posed a significant challenge to the currency's long-standing position in world markets. However, a study of the dollar across critical areas of international trade and finance suggests that the dollar has retained its standing in key roles. While changes in the global status of the dollar are possible, factors such as inertia in currency use, the large size and relative stability of the U.S. economy, and the dollar pricing of oil and other commodities will help perpetuate the dollar's role as the dominant medium for international transactions.

B y many measures, the U.S. dollar is the most important currency in the world. It plays a central role in international trade and finance as both a store of value and a medium of exchange. Many countries have adopted an exchange rate regime that anchors the value of their home currency to that of the dollar. Dollar holdings figure prominently in official foreign exchange (FX) reserves - the foreign currency deposits and bonds maintained by monetary authorities and governments. And in international trade, the dollar is widely used for invoicing and settling import and export transactions around the world.

Periodically, however, the dollar's preeminence as a cross-national currency has been questioned. The emergence of the euro in 1999 as a major currency and global competitor fueled the debate over the dollar's international role. More recently, the global shortage of dollars during the financial market crisis placed extraordinary strains on international firms needing to support their dollar-denominated assets and led to calls for changes in the international monetary system. Several developing countries, for example, have proposed that for certain transactions the dollar be replaced with a type of "world" currency based on International Monetary Fund special drawing rights. In addition, participants at the April 2009 meeting of the Group of Twenty finance ministers raised questions about the dollar's preeminence as a reserve currency, and People's Bank of China Governor Zhou Xiaochuan has pressed for a shift away from U.S. currency in various activities.

A change in the dominant role of the dollar in world markets would have consequences for the currency issuer and users alike. The dollar's international status helps insulate the U.S. economy from foreign shocks, reduces transaction costs in trade and finance, and contributes to the international transmission of U.S. shocks and monetary policy effects. For foreign economies, broad use of the dollar in reserves and in international transactions typically results in greater sensitivity of trade, inflation, 
and asset values to exchange rate movements between their currencies and the dollar. Furthermore, dollar banknotes - physical bills of different denominations - used abroad provide some foreign households and businesses with a more stable store of value and a sounder transaction currency, especially during periods of turbulence overseas.

This edition of Current Issues examines the role of the dollar across several key areas of international trade and finance. In each area, we provide evidence that the dollar retains its status as the dominant international currency in all major categories of use. We also touch on the factors that may have contributed to this continuing strength. One such factor is inertia in currency use in certain transactions. ${ }^{1}$ That is, the dollar's established and deep role in international markets may make it difficult for users to shift to a less entrenched currency. A second factor is the tendency of users to favor the currency of countries that have large economies and relatively strong output and employment growth as well as low and stable inflation. Finally, users may be predisposed to choose the dollar because it is linked to their own currency through their exchange rate regime and because key commodities such as oil and metals are priced in dollars.

While our evidence overall suggests that the dollar is likely to remain prominent as an international currency, its primacy cannot be taken for granted. The pound sterling entered the twentieth century as the dominant reserve currency but was later overtaken by the dollar. ${ }^{2}$ This observation serves as a reminder that_despite present trends—-transitions are possible.

\section{The Dollar as International Cash}

The dollar is a major form of cash currency around the world. The share of U.S. dollar banknotes estimated to be held outside the United States is substantial (Chart 1). ${ }^{3}$ Roughly 75 percent of hundred-dollar notes, 55 percent of fifty-dollar notes, and 60 percent of twenty-dollar notes are held abroad, while about 65 percent of all U.S. banknotes are in circulation outside the country. Approximately $\$ 580$ billion in physical U.S. currency outstanding was circulating overseas at the end of March 2009.

The stability of the U.S. dollar makes it an attractive currency in countries that are experiencing volatile economic and political conditions or that have histories of such risks. ${ }^{4}$ Although estimates of regional holdings can be imprecise, the bulk of dollar banknotes appear to be held in Russia, in former Soviet Union states, and in Latin America. In recent years, euros have

\footnotetext{
${ }^{1}$ See Krugman (1980).

2 The timing of this shift is debated. Eichengreen and Flandreau (2008) argue that the dollar first overtook sterling in the mid-1920s. Chinn and Frankel (2008) suggest that the change occurred after World War II.

${ }^{3}$ See U.S. Treasury Department (2006). Also see Table USCC-2, “U.S. Currency and Coin Outstanding and in Circulation," published in the U.S. Treasury Department Bulletin.

${ }^{4}$ See Hellerstein and Ryan (2009) for the forces influencing U.S. cash dollar holdings in foreign markets.
}

Chart 1

Share of U.S. Banknotes Held outside the United States

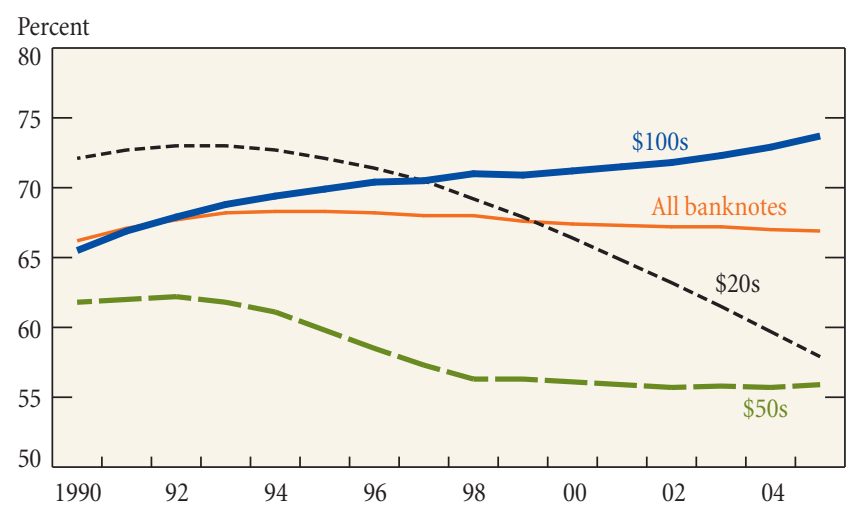

Source: Federal Reserve Bank of New York estimates, based on U.S. Treasury Department (2006).

also played a greater role as international cash, circulating more extensively outside the euro-area borders. Nevertheless, this physical currency is held mainly in countries in proximity to the euro area. ${ }^{5}$

Foreign holdings of U.S. banknotes offer some limited advantages to the United States. For example, the holdings create a larger base over which the country collects seigniorage. ${ }^{6}$ One way to estimate the seigniorage, or savings, that the United States derives from its currency held abroad is to compute a rate of return based on the interest earned on the Treasury portfolio held by the Federal Reserve; this calculation suggests annual savings of more than $\$ 30$ billion. ${ }^{7}$ However, these savings are offset somewhat by the costs to the United States of maintaining a currency outside national boundaries - for example, the expenses associated with controlling counterfeiting and providing depository vaults for new currency available to be exchanged for old dollars.

The benefits derived by the foreign holders of U.S. banknotes are potentially more substantial. Many of these holders enjoy a better store of value and an improved medium of exchange

\footnotetext{
${ }^{5}$ See European Central Bank (2009).

${ }^{6}$ The macroeconomic concept of seigniorage is often defined as a type of inflation tax: When an entity accepts banknotes (or currency) at a point in time, the accepted banknotes have a specific exchange value in current goods and services. However, if there is inflation, when the banknotes are exchanged back into goods and services at some future time, the amount of goods and services will be reduced because their price has become higher. This phenomenon represents a gain to the currency issuer and a tax on the currency holder. On the Federal Reserve balance sheet, seigniorage is represented by holdings of non-interestbearing currency in lieu of, for example, interest-bearing Treasury bills. The value of seigniorage is the interest-expense savings less the cost of maintaining the currency in circulation.

${ }^{7}$ Calculations are based on the annual reports of the Board of Governors of the Federal Reserve System. For assets, we use the tables entitled "Federal Reserve Bank Holdings of U.S. Treasury and Federal Agency Securities," selecting "U.S. Treasury Securities Held Outright." For interest, we use the tables entitled "Federal Reserve Banks' Combined Statements of Income," which present interest income on U.S. government securities.
} 
Table 1

\section{Countries Reporting U.S.-Dollar-Based Exchange Rate Arrangements}

\begin{tabular}{|c|c|c|c|c|}
\hline \multirow[b]{2}{*}{ Arrangement } & \multicolumn{4}{|c|}{ Number of Countries } \\
\hline & 1995 & 2000 & 2005 & 2007 \\
\hline $\begin{array}{l}\text { Dollarized or formed } \\
\text { currency board }\end{array}$ & 9 & 8 & 7 & 7 \\
\hline $\begin{array}{l}\text { Pegged exchange rate regime } \\
\text { against dollar }\end{array}$ & 82 & 85 & 90 & 89 \\
\hline $\begin{array}{l}\text { Maintained managed floats with } \\
\text { dollar as reference currency }\end{array}$ & 6 & 8 & 6 & 8 \\
\hline Total reporting & 207 & 207 & 207 & 207 \\
\hline $\begin{array}{l}\text { Memo: } \\
\text { Currency linked to dollar (percent) }\end{array}$ & 47 & 49 & 50 & 50 \\
\hline $\begin{array}{l}\text { Gross domestic product linked } \\
\text { to dollar (percent) }\end{array}$ & 21 & 29 & 31 & 36 \\
\hline
\end{tabular}

Sources: Reinhart and Rogoff (2004); Ilzetzki, Reinhart, and Rogoff (2008); author's calculations.

relative to their home currencies, especially when local macroeconomic and political conditions are risky. Still, foreign nations lose the seigniorage they otherwise might have collected if their own currency were fully in use locally.

\section{The Dollar in Exchange Rate Arrangements}

\section{and FX Reserves}

The dollar serves as a central currency in the exchange rate arrangements of many countries. When a country to some degree fixes its exchange rate in relation to the dollar, it is making a commitment to monetary and sometimes fiscal policies aimed at maintaining a stable value of its currency relative to the dollar. While monetary policy tools in the foreign economy generally could be used to achieve other goals, such as influencing inflation or output directly, when the currency value is kept within rigid bounds relative to the dollar, monetary policy instead tends to be directed at maintaining the bilateral currency value.

A useful measure of the dollar's prominence in this area of international finance is the number of countries with dollarbased exchange rate arrangements. To determine that figure, we group currency arrangements according to whether countries have dollarized or have formed currency boards using the dollar, have a pegged exchange rate against the dollar, or maintain managed floats with the dollar as a reference currency (Table 1). Exchange rate arrangements can be difficult to categorize, however, with de facto arrangements often different from reported de jure arrangements. Although the information in the table is drawn from a prominent 2004 study by Reinhart and Rogoff (updated in Ilzetzki, Reinhart, and Rogoff [2008]), there is no consensus on the identification of these regimes. Other categorizations include those provided by the International Monetary Fund in its report "Exchange Arrangements and Exchange Restrictions" and in research by Shambaugh (2004) and Levy-Yeyati and Sturzenegger (2003). Each study reaches
Chart 2

\section{Foreign Currency Reserve Holdings}

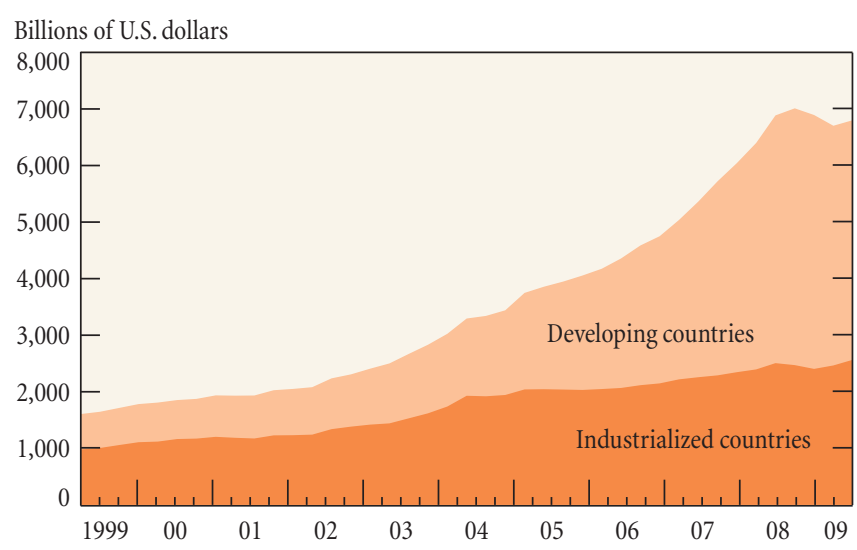

Source: International Monetary Fund, Currency Composition of Official Foreign Exchange Reserves (COFER) data.

different conclusions about the exchange rate regimes of countries because of differences between de jure and de facto regimes and because the de facto regimes are defined using alternative methods and assumptions.

According to the Reinhart and Rogoff categorizations (Table 1), seven countries currently are dollarized or have currency boards using the dollar and eighty-nine have a pegged exchange rate against the dollar. The share of countries linking their currency to the dollar in some manner has been stable since 1995 , and this group represents more than a third of world GDP (excluding the United States).

Another indicator of the dollar's status is its prominence in the portfolios of foreign governments' foreign exchange reserve accounts. These reserve balances, which are essentially the governments' foreign currency savings, can be quite large. Foreign exchange reserve holdings grew sharply over the past decade and exceeded $\$ 7$ trillion in 2008 (Chart 2). Developing countries accounted for most of the increase, with China taking the lead. Indeed, as of first-quarter 2009, China held 46 percent of the reserves of developing countries.

In 2009, dollar assets accounted for about two-thirds of the reserve assets of industrialized and developing countries (Chart 3). Among industrialized countries, a sharp jump in the dollar share occurred between 1995 and 2000. The rise can be explained primarily by changes in the reserve holdings of euroarea countries. With the introduction of the euro, the legacy currency reserves of euro-area countries- the deutsche marks, francs, lira, and other currencies replaced by the euro-were reclassified as local currencies and therefore were no longer considered foreign currency reserves; this shift in the composition of the countries' reserve portfolios meant that the dollar assumed a much larger share of the remaining reserves. Subsequently, the dollar share declined only modestly in the portfolios of industrialized countries. 
Chart 3

\section{U.S. Dollar Assets in Foreign Currency Reserves}

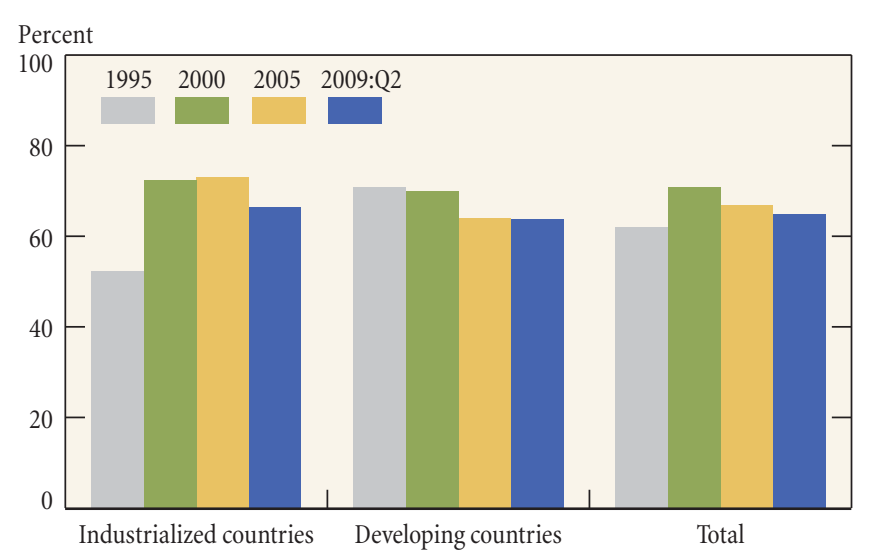

Sources: International Monetary Fund, Currency Composition of Official Foreign Exchange Reserves (COFER) data; Board of Governors of the Federal Reserve System staff estimates.

Note: Amounts are valued at current exchange rates.

Chart 3 also shows that the reported dollar share in the reserve portfolios of developing countries appears to have declined over the past decade. However, such an interpretation is misleading. Most of the decline reflects the dollar's depreciation between 2005 and 2008, which raised the value, and hence the share, of other currencies in the portfolios. If we adjust the portfolio shares to be valued at constant exchange rates, the dollar share in developing countries' reserve portfolios has actually been quite stable since 2000. Furthermore, although a decline in reserve holdings occurred during the global financial crisis, the dollar share of reserve holdings for both industrialized and developed countries remained high.

There is a long history of debate on the prospect of a change in the dollar's role in international reserve portfolios. Over the past decade, many commentators have discussed whether the advent of the euro in 1999 would reduce that role. The theme recurred in the context of the sustainability of the U.S. current account deficit. More recently, the dollar's place in foreign currency reserves has received renewed attention. People's Bank of China Governor Zhou Xiaochuan has called for a shift away from the dollar, while U.S. Treasury Secretary Timothy Geithner has confirmed the currency's continuing central role. ${ }^{8}$ The dollar's prominence as a reserve currency was also discussed at the April 2009 meeting of the Group of Twenty finance ministers. Needless to say, the composition of reserve holdings is not mandated by the central bodies of the international monetary system, but instead is decided by individual countries. Among the reasons cited for a possible change in the dollar's role are the relatively high growth rates of other parts of the world, the large size of the euro area,

\footnotetext{
${ }^{8}$ See http://www.pbc.gov.cn/english//detail.asp?col=6500\&ID=178 and
} http://www.treas.gov/press/releases/tg68.htm, respectively. and potential changes in patterns of economic and military strength. ${ }^{9}$

A shift away from dollar assets, including Treasury securities, could be a concern for the United States if divestiture triggers higher funding costs. In the extreme, private investors could spur a run on dollar assets that leads to a destabilizing fall in the value of the currency and a sharp rise in U.S. interest rates. However, such a drastic outcome appears unlikely.

Overall, despite market turbulence and substantial movements in the value of the dollar over the past decade, the dollar has not declined in prominence either as a central currency for exchange rate arrangements or as an international reserve currency. The future of the dollar in this context continues to be the subject of discussion and policy statements, but the currency's status has been maintained.

The Dollar in the FX Markets and as an Invoicing Currency The dollar is a leading transaction currency in the foreign exchange markets and a key invoicing currency in international trade. With an 86 percent share of FX transaction volume-more than twice the share of the euro- the dollar continues to dominate these markets (Table 2). Turnover volumes in the foreign exchange markets have more than doubled in the past decade, implying large numbers of transactions measured in reference to, or involving, the dollar. In the FX markets, higher transaction volumes contribute to lower bid-ask spreads and reduced implicit transaction costs for using dollars_-advantages that in turn reinforce the use of the dollar in these transactions. This selfreinforcing pattern exemplifies the inertia phenomenon described earlier: Once a currency has an established and deep role in international markets, it is not easily displaced from this role.

Another likely contributor to the dollar's leading role in foreign exchange transactions is the currency's widespread use in the invoicing of international trade. To assess the prevalence of the dollar as an invoicing currency, we compare the percentage of each country's exports invoiced in dollars with the percentage of the country's total exports destined for the United States (Chart 4). This exercise reveals the extent to which foreign producers choose the dollar as a "vehicle currency" for their trade with nations other than the United States.

In the chart, the diagonal line represents a situation in which all of the dollar invoicing of a country's exports is explained by the U.S. share of the country's total exports. In other words, if all exports to the United States were invoiced in dollars, and these were the only exports invoiced this way, the chart's twenty-four country observations would fall along the diagonal line. However, the observations are significantly to the right of the line, indicating

\footnotetext{
${ }^{9}$ The prospects of the dollar as an international reserve currency have been studied by Chinn and Frankel (2007) and Papaioannou and Portes (2008), among others; the papers cited argue that the euro is poised for a more prominent future
} role. Also see the papers in Pisani-Ferry and Posen (2009). 
Table 2

\section{Turnover in Traditional Foreign Exchange Markets Percent}

\begin{tabular}{lcccc} 
Currency & 1995 & 2001 & 2004 & 2007 \\
\hline U.S. dollar & 83.3 & 90.3 & 88.7 & 86.3 \\
Euro & $53.7^{\mathrm{a}}$ & 37.6 & 36.9 & 37.0 \\
Yen & 24.1 & 22.7 & 20.2 & 16.5 \\
$\begin{array}{l}\text { Other industrialized } \\
\quad \text { currencies }\end{array}$ & & & & \\
$\begin{array}{l}\text { Emerging market } \\
\quad \text { currencies }\end{array}$ & 24.2 & 33.9 & 38.6 & 40.5 \\
\hline
\end{tabular}

Memo:

Average daily turnover

$\begin{array}{lllll}\text { (billions of U.S. dollars) } & 1,150 & 1,420 & 1,970 & 3,210\end{array}$

Source: Bank for International Settlements.

Note: Currency shares total 200 percent in each column because each transaction involves two currencies.

a Legacy currencies replaced by the euro include the deutsche mark, French franc, Netherlands guilder, and European Currency Unit.

${ }^{\mathrm{b}}$ Currencies are the pound sterling, Swiss franc, Australian dollar, Canadian dollar, Swedish krona, Norwegian krone, New Zealand dollar, and Danish krone.

that use of the dollar in export invoicing is substantial and far exceeds what could be explained by country exports to the United States. This reliance on the dollar for invoicing exports to nations other than the United States may reflect inertia in currency use, the large size and relatively stability of the U.S. economy, or exchange rate arrangements that link the currency of the destination country or the exporting country to the dollar. In addition, it may reflect the incentive for exporters to limit the movements of their prices relative to those of competitors by choosing the invoicing currency used by the majority of producers in the industry. A final factor is the incentive to invoice in a currency that offers the best hedge against cost fluctuations stemming from relevant movements in aggregate demand and wages in the source and destination countries (Goldberg and Tille 2008).

It is reasonable to consider whether the advent of the euro has changed dollar use as a currency for invoicing international trade. Research on the evolution of invoicing patterns over time finds that the euro has not substantially eroded the use of dollars for this purpose. ${ }^{10}$ The euro is used extensively for invoicing trade of the sixteen countries that have adopted the currency-both in transactions among themselves and with other markets—but not broadly in other regions. This activity is well documented by the European Central Bank (2009) in a series of reports on the international role of the euro and in related research by Kamps (2006) and Goldberg (2007). Other research shows that dollar use in the invoicing of international trade is associated with relatively low transmission of exchange rate movements to U.S. import prices and thus a reduced impact of exchange rate movements on U.S. consumers (Goldberg and Tille 2006; Goldberg and Dillon 2007).

\footnotetext{
${ }^{10}$ Goldberg and Tille (2008, 2009); Goldberg (2007).
}

Chart 4

Dollar Use in the Invoicing of Exports

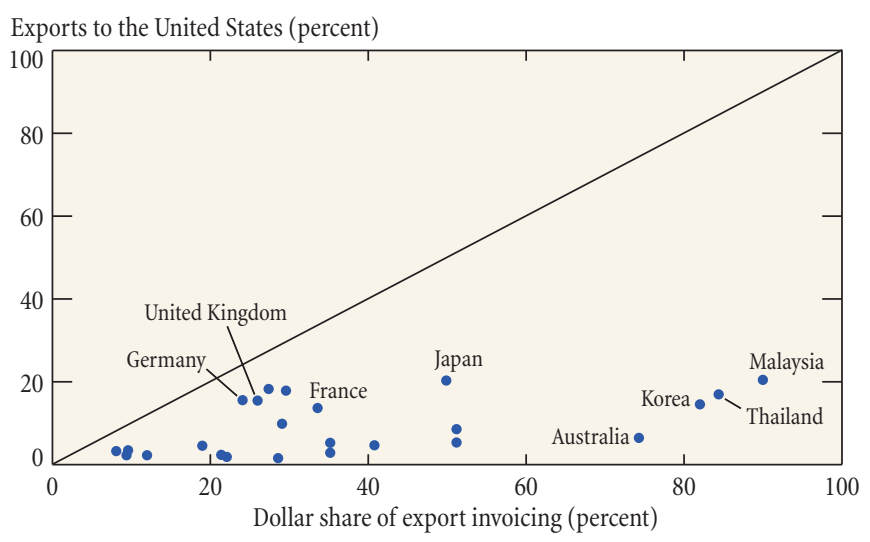

Source: Goldberg and Tille (2008).

Note: Observations cover various years from 2000 to 2007.

The Dollar in International Financial Transactions

The international debt markets are another area in which the dollar serves as a prominent currency. ${ }^{11}$ The currency's status is exemplified by the share of all outstanding debt securities, issued anywhere in the world, denominated in dollars. According to this measure, the dollar's share stands at approximately 39 percent, down only slightly from a high of 42 percent in 1999 (Chart 5). Another key gauge is the dollar-denominated share of all securities sold outside the issuing country and in a currency different from that of the issuer's country. This narrower measure-termed "international debt securities" in the chart—suggests that the dollar also continues to be a significant currency for debt when borrowers turn to external markets and foreign currency financing. In 2009 , the dollar accounted for almost half of these debt securities.

An analysis of currency use by region suggests that in debt issuance by individuals and governments, as in other areas of international trade and finance, the euro has not had a sizable impact on the dollar. The dollar remains the primary financing currency for issuers in the Middle East, Latin America, Asia, and the Pacific area. The euro dominates issuances in Scandinavia, the United Kingdom, and the new member states of the European Union. Issuers in Africa rely on dollars and euros about equally.

The dollar also plays an important role in the cross-border foreign currency liabilities of banks in countries that report data to the Bank for International Settlements. These outstanding liabilities are to creditors outside the reporting country and in a currency other than that of the reporting country. Over the past decade, such liabilities have grown substantially with respect to bank and nonbank counterparties (Chart 6), with liabilities to nonbanks (including money market mutual funds) expanding slightly faster than liabilities to banks.

\footnotetext{
${ }^{11}$ For more detail, see European Central Bank (2009), Coeurdacier and Martin (2007), and Thimann (2008).
} 
Chart 5

\section{U.S. Dollar Share of Debt Securities Outstanding}

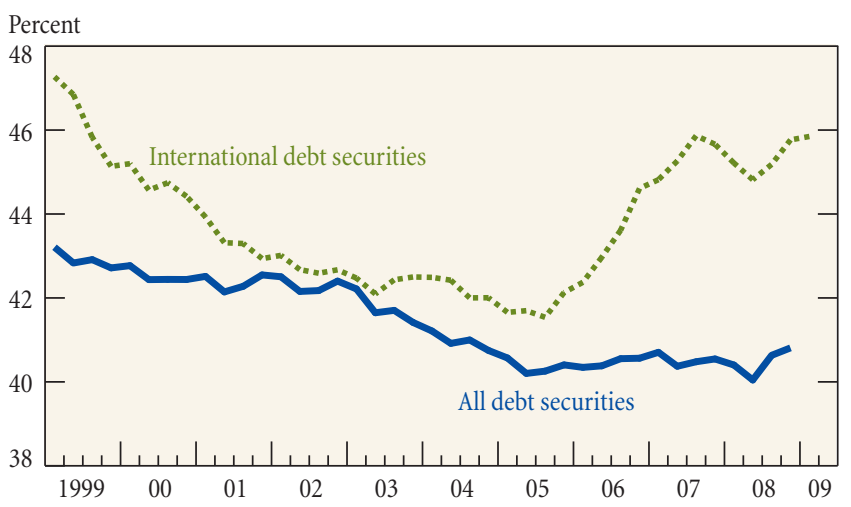

Source: European Central Bank (ECB) estimates using Thomson Financial data.

Note: The "all debt securities" measure corresponds to the ECB series on "global" debt securities; the "international debt securities" measure corresponds to the ECB "narrow" measure-defined as securities sold outside the issuing country, excluding debt in the issuer's own currency.

The dollar continues to claim a dominant share of these cross-border liabilities to both nonbank and bank counterparties (Chart 7). The slight decline in the dollar share in recent years is likely attributable to measures that use current, rather than constant, exchange rates.

Further evidence of the dollar's continued prominence is provided by the strong dollar funding needs of non-U.S. banks during the recent financial market turbulence. ${ }^{12}$ Data on crossborder-liability denominations show that by June 2008, non-U.S. banks had accumulated approximately $\$ 27$ trillion in cross-border liabilities denominated in currencies other than that of their home country. More than $\$ 18$ trillion of this amount was denominated in dollars. Accordingly, when the credit markets tightened, these banks had substantial dollar funding needs. ${ }^{13}$ The disruption of dollar availability abroad was partially addressed by the foreign exchange swap lines established between the Federal Reserve and other central banks. ${ }^{14}$ During the early stages of the recent crisis, prior to the expansion of the swap lines, the volumes of dollars available and drawn upon totaled less than $\$ 70$ billion. By the end of 2008, expansion of dollar availability through the central bank dollar swap lines, combined with the growing financing needs outside the United States, brought amounts drawn by central banks to

\footnotetext{
12 This phenomenon is explored in detail by McGuire and von Peter (2009). Disruptions to the supply of dollars during the financial turmoil were partially addressed when the Federal Reserve created and expanded foreign currency swap facilities with other central banks. The Federal Reserve's Term Auction Facility and reciprocal currency arrangements with other central banks increased the available supply of dollars. In some cases, the Federal Reserve acted as a dollar lender of last resort to some segments of the financial sector.

13 See Coffey et al. (2009).

14 See Goldberg, Kennedy, and Miu (2010).
}

\section{Chart 6 \\ Cross-Border Foreign Currency Liabilities of Non-U.S. Banks}

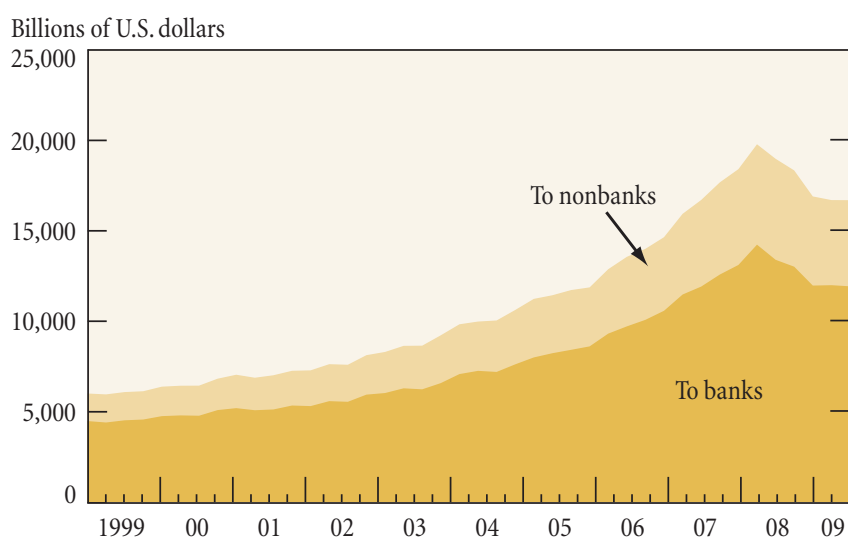

Source: Bank for International Settlements, cross-border locational-by-residence banking statistics.

Note: Figures exclude liabilities in issuer's own currency.

\section{Chart 7 \\ U.S. Dollar Share of Cross-Border Foreign Currency Liabilities of Non-U.S. Banks}

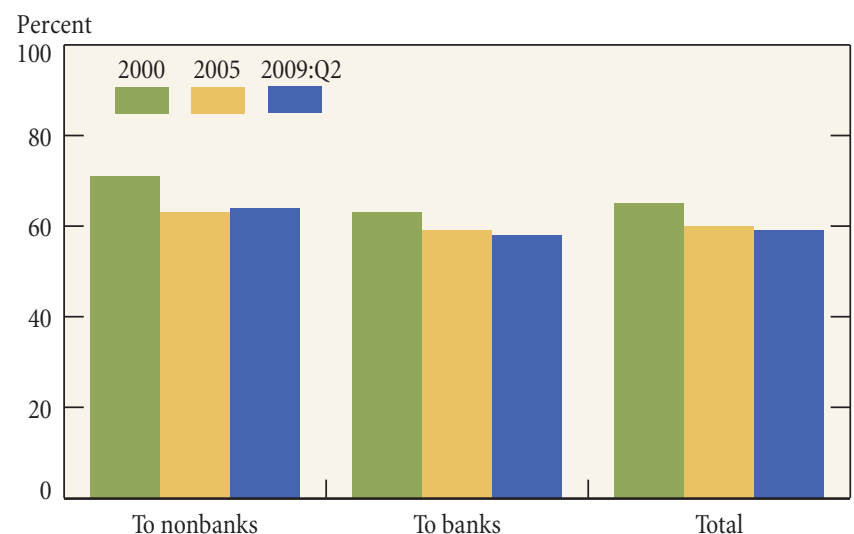

Source: Bank for International Settlements, cross-border locational-by-residence banking statistics.

Note: Figures exclude liabilities in issuer's own currency.

more than $\$ 560$ billion. The trade activity and range of financial transactions associated with these figures suggest that the dollar remains a leading transaction currency.

\section{Conclusion}

The international role of the dollar remains substantial a decade after the introduction of the euro, and despite changes in the value of the dollar and the financial turmoil that began in 2007. Use of the currency abroad continues to have a range of consequences 
for the United States. In general, it helps insulate the U.S. economy from foreign shocks, reduces transaction costs in trade and finance, and extends the international transmission of U.S. policy. For non-U.S. economies, broad use of the currency in reserves and in international transactions is typically associated with greater sensitivity of trade, inflation, and asset values to international movements in the value of the dollar.

As the size and structure of the global economy change, international currency use may change as well. Despite evidence of the dollar's vitality, the currency's preeminence could diminish in the future. Indeed, historical precedent exists for the rise and fall of the international status of currencies. In the first half of the twentieth century, for example, the dollar overtook the pound sterling as the dominant reserve currency.

Changes to the global economy could have major implications for the international transmission of shocks, the value of the dollar, and welfare across economies. Accordingly, it seems important for policymakers to monitor use of the dollar in international economic activity and to understand the potential causes and consequences of the dollar's changing international role.

\section{References}

Bank for International Settlements. Various issues. Triennial Central Bank Survey of Foreign Exchange and Derivatives Market Activity.

Chinn, Menzie, and Jeffrey A. Frankel. 2007. "Will the Euro Eventually Surpass the Dollar as Leading International Reserve Currency?" In Richard H. Clarida, ed., G7 Current Account Imbalances: Sustainability and Adjustment 2007, 283-322. Chicago: University of Chicago Press.

2008. "Will the Euro Rival the Dollar? A Debate." International Finance 11, no. 1 (spring): 49-73.

Coeurdacier, Nicolas, and Philippe Martin. 2007. "The Geography of Asset Trade and the Euro: Insiders and Outsiders." Centre for Economic and Policy Research Discussion Paper no. 6032, January.

Coffey, Niall, Warren B. Hrung, Hoai-Luu Nguyen, and Asani Sarkar. 2009. "The Global Financial Crisis and Offshore Dollar Markets." Federal Reserve Bank of New York Current Issues in Economics and Finance 15, no. 6 (October).

Eichengreen, Barry, and Marc Flandreau. 2008. "The Rise and Fall of the Dollar, or When Did the Dollar Replace Sterling as the Leading Reserve Currency?” Unpublished paper, University of California at Berkeley.

European Central Bank. 2009. “The International Role of the Euro." July.

Goldberg, Linda S. 2007. "Trade Invoicing in the Accession Countries: Are They Suited to the Euro?" In Jeffrey A. Frankel and Christopher A. Pissarides, eds., NBER International Seminar on Macroeconomics 2005, 357-93. Cambridge, Mass.: MIT Press.
Goldberg, Linda S., Craig Kennedy, and Jason Miu. 2010."Central Bank Dollar Swap Lines and Overseas Dollar Funding Costs." Federal Reserve Bank of New York Staff Reports, no. 429, January.

Goldberg, Linda S., and Cédric Tille. 2006. “The International Role of the Dollar and Trade Balance Adjustment.” Group of Thirty Occasional Paper no. 71.

.2008. "Vehicle Currency Use in International Trade." Journal of International Economics 76, no. 2 (December): 177-92.

2009. "Micro, Macro, and Strategic Forces in International Trade Invoicing." Federal Reserve Bank of New York Staff Reports, no. 405, November.

Goldberg, Linda S., and Eleanor Wiske Dillon. 2007. "Why a Dollar Depreciation May Not Close the U.S. Trade Deficit." Federal Reserve Bank of New York Current Issues in Economics and Finance 13, no. 5 (June).

Hellerstein, Rebecca, and William Ryan. 2009."The Determinants of International Flows of U.S. Currency." Federal Reserve Bank of New York Staff Reports, no. 400, October.

Ilzetzki, Ethan 0., Carmen M. Reinhart, and Kenneth S. Rogoff. 2008. Background material on "Exchange Rate Arrangements into the 21st Century: Will the Anchor Currency Hold?" Unpublished paper, Harvard University. Available at http://www .economics.harvard.edu/faculty/rogoff/files/ERA_Background_Material.htm.

Kamps, Annette. 2006. "The Euro as Invoicing Currency in International Trade." European Central Bank Working Paper no. 665, August.

Krugman, Paul. 1980. "Vehicle Currencies and the Structure of International Exchange." Journal of Money, Credit, and Banking 12, no. 3 (August): 513-26.

Levy-Yeyati, Eduardo, and Federico Sturzenegger. 2003. “To Float or to Fix: Evidence on the Impact of Exchange Rate Regimes on Growth." American Economic Review 93, no. 4 (September): 1173-93.

McGuire, Patrick, and Goetz von Peter. 2009. “The U.S. Dollar Shortage in Global Banking." Bank for International Settlements Quarterly Review, March: 47-63.

Papaioannou, Elias, and Richard Portes. 2008. "Costs and Benefits of Running an International Currency." European Commission European Economy Economic Papers, no. 348, November.

Pisani-Ferry, Jean, and Adam S. Posen, eds. 2009. The Euro at Ten: The Next Global Currency? Washington, D.C.: Peter G. Peterson Institute for International Economics.

Reinhart, Carmen, and Kenneth Rogoff. 2004. "The Modern History of Exchange Rate Arrangements: A Reinterpretation." Quarterly Journal of Economics 119, no. 1 (February): 1-48.

Shambaugh, Jay C. 2004. "The Effect of Fixed Exchange Rates on Monetary Policy." Quarterly Journal of Economics 119, no. 1 (February): 301-52.

Thimann, Christian. 2008. "Global Roles of Currencies.” International Finance 11, no. 3 (winter): 211-45.

U.S. Treasury Department. 2006. “The Use and Counterfeiting of United States Currency Abroad, Part 3." Final Report to the Congress by the Secretary of the Treasury, in Consultation with the Advanced Counterfeit Deterrence Steering Committee. September.

\section{ABOUT THE AUTHOR}

Linda S. Goldberg is a vice president in the International Research Function of the Federal Reserve Bank of New York.

Current Issues in Economics and Finance is published by the Research and Statistics Group of the Federal Reserve Bank of New York. Linda S. Goldberg and Charles Steindel are the editors.

The views expressed in this article are those of the author and do not necessarily reflect the position of the Federal Reserve Bank of New York or the Federal Reserve System. 